\title{
Current developments of microfiltration technology in the dairy industry
}

\author{
Luciana V. SABOYA ${ }^{\mathrm{a}}$, Jean-Louis MAUBOIS ${ }^{\mathrm{b} *}$ \\ a Escola Superior de Agricultura "Luiz de Queiroz" (ESALQ - USP), \\ Av. Pádua Dias 11, 13418-900/Piracicaba, SP, Brasil \\ ${ }^{\mathrm{b}}$ Laboratoire de Recherches de Technologie Laitière, INRA, \\ 65 rue de Saint Brieuc, 35042 Rennes Cedex, France
}

(Received 2 May 2000; accepted 27 September 2000)

\begin{abstract}
This paper deals with the most recent developments of cross flow microfiltration (CFMF), some of them just patented, in the dairy industry. Combination of the use of uniform transmembrane hydraulic pressure concept (UTP) with its different ways of carrying out microfiltrate recirculation, longitudinal porosity gradient and of new ceramic membrane materials allows nowadays to get a differential separation of each category of milk particles. Pretreatment by CFMF of incoming milk is used for the production of low heated fluid milks having a flavor similar to that of raw milk and a shelf life 3 to 5 times longer than that of classical products. Results observed in the retention by the MF membrane of pathogenic bacterial species allow it to be said that the hygienic safety of cheeses made from raw MF milk is, at least, equal or even higher than that of cheeses made from pasteurized milk. Numerous other applications of CFMF are under development such as removal of residual fat from whey or the clarification and the removal of bacteria from cheese brine but the most promising are undoubtedly the differential separation of micellar casein and of small milk fat globules. With the products obtained on both sides of the MF membrane, dairy technology will have the possibility not only to improve yield and quality of many dairy products but also to create a diversified range of new textures.
\end{abstract}

microfiltration / membrane / liquid milk / native casein / brine / whey / cheese

Résumé — Développements actuels de la technologie de microfiltration dans l'industrie laitière. Cet article traite des développements les plus récents, certains tout juste brevetés, de la microfiltration tangentielle dans l'industrie laitière. La combinaison de l'utilisation du concept de pression transmembranaire uniforme, avec ses différentes possibilités de mise en œuvre : recirculation du microfiltrat, gradient de porosité longitudinal, et de nouveaux matériaux membranaires céramiques

* Correspondence and reprints

Tel.: (33) 2234853 22; fax: (33) 2234853 50; e-mail: maubois @ labtechno.roazhon.inra.fr 
permet maintenant d'obtenir une séparation différentielle de chaque catégorie de particule laitière. Le prétraitement par microfiltration tangentielle du lait est utilisé pour la production de lait de consommation peu chauffé ayant une flaveur similaire à celle du lait cru et une durée de vie 3 à 5 fois supérieure à celle des produits classiques. Les résultats observés sur la rétention par les membranes de microfiltration d'espèces bactériennes pathogènes permet de dire que la sécurité hygiénique des fromages fabriqués à partir de lait cru microfiltré est au moins équivalente et même supérieure à celle des fromages fabriqués à partir de lait pasteurisé. Plusieurs autres applications de la microfiltration tangentielle sont en cours de développement, comme l'extraction de la matière grasse résiduelle du lactosérum ou la clarification et la séparation des bactéries des saumures de fromage, mais la plus prometteuse est indubitablement la séparation différentielle de la caséine micellaire et des petits globules gras du lait. Avec les produits obtenus des deux côtés de la membrane de microfiltration, la technologie laitière aura la possibilité non seulement d'améliorer le rendement et la qualité de beaucoup de produits laitiers mais aussi de créer une gamme diversifiée de nouvelles textures.

microfiltration / membrane / lait de consommation / caséine native / saumure / lactosérum / fromage

\section{INTRODUCTION}

Microfiltration (MF) like all the other membrane separation processes is a technique which allows the differential concentration in the liquid retained by the membrane, named MF retentate, of the components with a size bigger than the average pore diameter of the membrane. The liquid going through the MF membrane is named microfiltrate. It contains, at the same concentration as those existing in the incoming treated liquid, the components with a size smaller than the average pore diameter.

As shown in Figure 1, pore diameter of MF membranes ranges from $10 \mu \mathrm{m}$ to $0.1 \mu \mathrm{m}$, which means MF will be used for the specific separation of the particles suspended in liquids.

Milk contains particles of which the size distribution ranges (Tab. I) are relatively well separated. By decreasing size, they are somatic cells $(15-6 \mu \mathrm{m})$, fat globules $(15-0.2 \mu \mathrm{m})$, bacteria $(6-0.2 \mu \mathrm{m})$ and casein micelles $(0.3-0.03 \mu \mathrm{m})$ [40].

The breakthrough of MF in the dairy industry came in the 1980s with the development of new ceramic membranes comprising a multichannel geometry and a highly permeable support [15] which made industrially feasible the revolutionary hydraulic concept proposed by Sandblom [47]: the uniform and low transmembrane pressure (UTP). The UTP concept overcomes most of the heterogeneous fouling of the MF membrane which results from the high cross flow velocities required for obtaining both high permeation fluxes and accurate selectivity.

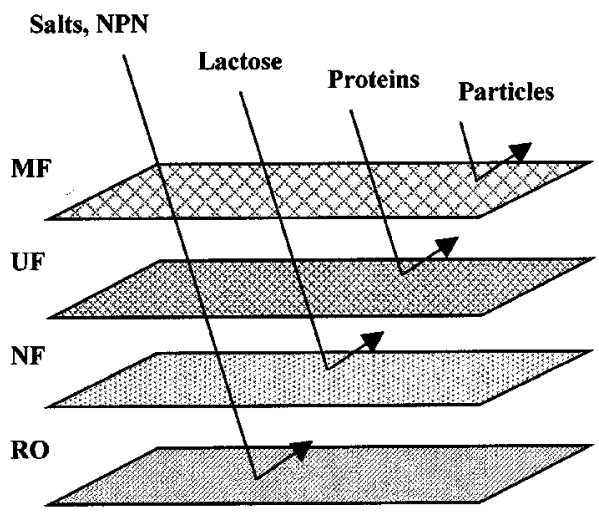

Figure 1. Illustration of filtration membranes: microfiltration (MF), ultrafiltration (UF), nanofiltration (NF), reverse osmosis (RO).

Figure 1. Illustration de la filtration membranaire : microfiltration (MF), ultrafiltration (UF), nanofiltration (NF), osmose inverse (OI). 
Table I. Relative diameters of milk particles (adapted from [40]).

Tableau I. Diamètre moyen des particules du lait (adopté de [40]).

\begin{tabular}{lr}
\hline Component & \multicolumn{1}{c}{ Size $(\mu \mathrm{m})$} \\
\hline Casein micelles & $0.300-0.032$ \\
Bacteria & $15.000-0.200$ \\
Fat globules & $6.000-0.200$ \\
Somatic cells & $15.000-6.000$ \\
\hline
\end{tabular}

Cross flow microfiltration (CFMF) has emerged as an industrial separation technology in the dairy industry for at least three main applications: (i) removal of bacteria [25, 50], (ii) whey defatting [39], and (iii) micellar casein enrichment of the cheesemaking [9], but numerous other applications are currently being investigated, such as selective separation of somatic cells from raw whole milk, whey or milk protein fractionation or milk fat separation.

\section{MICROFILTRATION ENGINEERING CONSIDERATIONS}

Efficiency of any membrane separation technologies is governed by many parameters: amongst them the most active are the materials constituting the membrane and its support and the hydrodynamics of the whole equipment.

\subsection{Membranes}

In the early 80 s, attempts were made to use MF as an alternative technology to centrifugation for clarification and microbial epuration of whey $[32,33,41]$ but the available organic membrane materials (polysulfone and polycarbonate) were not satisfactory both in terms of flux and selectivity as well as in terms of mechanical heat and chemical stability [20]. A novel opportunity was offered for the envisaged applications in the dairy industry by the commercial emergence of the ceramic-based membranes [14] originally developed for isotope enrichment in the nuclear industry. Nevertheless, if the chemical and heat stability of this new membrane generation was corresponding fully to requirements of the dairy industry, flux decline and changes in selectivity versus time were so high [42] that none of the proposed processes [16, 42] could be considered as suitable for industrial scale-up. Most of the encountered problems in controlling the fouling of MF membranes over time by the deposited milk components were solved by the carrying out of the hydraulic concept of the uniform transmembrane pressure (UTP) proposed as early as 1974 by Sandblom [47]. The different membrane and system configurations currently used for obtaining hydraulic UTP are described later.

Pore sizes of MF ceramic membranes range from $20 \mu \mathrm{m}$ to $0.1 \mu \mathrm{m}$. Structures and methods of manufacture of these membranes are described by Rios et al. [44]. In a first approach, membranes consist of two parts: a macroporous support and the active membrane coated onto the surface. The supporting materials made from alumina (the most developed), carbon, stainless steel or $\mathrm{SiC}$ (not employed in the food industry because of its low stability at high $\mathrm{pH}$ ) must drain away the permeate without any hydrodynamic resistance and thus have a minimum pore diameter of $10 \mu \mathrm{m}$. The membrane layer (usually composed of alumina, titanium oxide or zirconia or a mixture of both oxides) is formed by coating the support with a colloidal suspension of highly divided powder (more than $100 \mathrm{~m}^{2} \cdot \mathrm{g}^{-1}$ ), then sintered to the support by firing. Membrane thickness is around to $3-5 \mu \mathrm{m}$ [18]. Narrow pore size distribution is obtained through both accurate control of the colloidal particle size and sintering of two, or sometimes three successive layers (Société des Céramiques Techniques - SCT, personal communication). 
Such a restriction of the width of the Gaussian distribution curve of the pore diameter can improve significantly the selectivity of the MF process. For example, substitution of a $1.4 \mu \mathrm{m}$ pore size Membralox by a $1.4 \mu \mathrm{m}$ Sterilox i.e. with the same average pore diameter but with a much narrower pore size distribution increases the MF retention of milk bacteria by $2 \log$ [26]. As said before, ceramic membranes are the only ones that satisfy all the requirements of the applications in the dairy industry i.e. a strong mechanical resistance which allows the use of high recirculation velocities of viscous MF retentates, a wide tolerance to $\mathrm{pH}$ ( 0.5 to 13.5) allowing its usage for cleaning in place of caustic soda (up to $3 \%$ ), of nitric acid (up to $2 \%$ ) - but phosphoric and hydrofluoric acids should be avoided - and of sodium hypochlorite for sanitation. Membranes were configured originally in monotubes with an inner diameter ranging from 3 to $8 \mathrm{~mm}$ and a length around $85 \mathrm{~cm}$. Recent designs concern mostly the multichannel configuration with either classical cylindrical channels or various cross section forms: square, trifolium or "daisy" like those proposed by the Tami ${ }^{\circledR}$ Co. Monotubular and multichannel monoliths, whose the length is now more than $1 \mathrm{~m}$ are assembled in bundles placed in stainless steel housings named MF modules. The area developed in one module ranges from $0.2 \mathrm{~m}^{2}$ to $10 \mathrm{~m}^{2}$ or more according to the manufacturer. Most of the proposed modules are steam sterilizable but in practice, the operating temperatures are limited not by the membranes, which can withstand temperatures of several hundred ${ }^{\circ} \mathrm{C}$, but by the other components of the MF module such as gaskets.

\subsection{MF equipment configurations}

Except for some old equipment for whey defatting, the first industrial application of MF in the dairy industry $[8,29]$, most of the current MF plants operate according to the hydraulic concept of UTP. To overcome the rapid fouling of the MF membrane resulting from the necessary high cross-flow velocity conditions of the MF retentate (more than $7 \mathrm{~m} \cdot \mathrm{s}^{-1}$ ), Sandblom [47] has suggested recirculating the MF permeate, in such flow conditions that the transmembrane pressure is low and uniform all along the membrane (Fig. 2). In the method patented by Alfa Laval [19], the permeate compartment filled with plastic balls is pressurized by pumping the permeate in a loop parallel to the direction of the retentate flow. A basic MF system comprises a feed tank, a feed pump and two recirculation loops: one for the MF retentate including one or a multiple number of two modules and a heat exchanger - one for the MF permeate. Both loops have outlet valves regulated by sensors for a continuous production of the two separated fluids.

Recent developments in ceramic membrane technology have allowed the suppression of the MF permeate recirculation loop, and thus a decrease in the investment cost per $\mathrm{m}^{2}$ of installed equipment and a saving of some consumed energy. The first one, known as Membralox GP ${ }^{\circledR}$, was developed by SCT [10]. The requested counterpressure in the permeate side is obtained by a continuous variation of the porosity of the membrane ceramic support. The second one very recently proposed by Tami Co, named "Isoflux ${ }^{\circledR}$ ", claims obtaining UTP by a continuous gradient of MF membrane thickness. Both developments must be used for welldefined applications, the porosity gradient of the membrane support as well as the thickness gradient of the membrane being both built for precise flux and selectivity.

\subsection{Starting procedure}

MF equipment must be started with care in order to avoid dramatic and fast fouling. They are firstly filled with warm water $\left(52{ }^{\circ} \mathrm{C}\right)$ with the air exhaust valve open for removing air bubbles. Then, hydraulic recirculation parameters which will be used on 


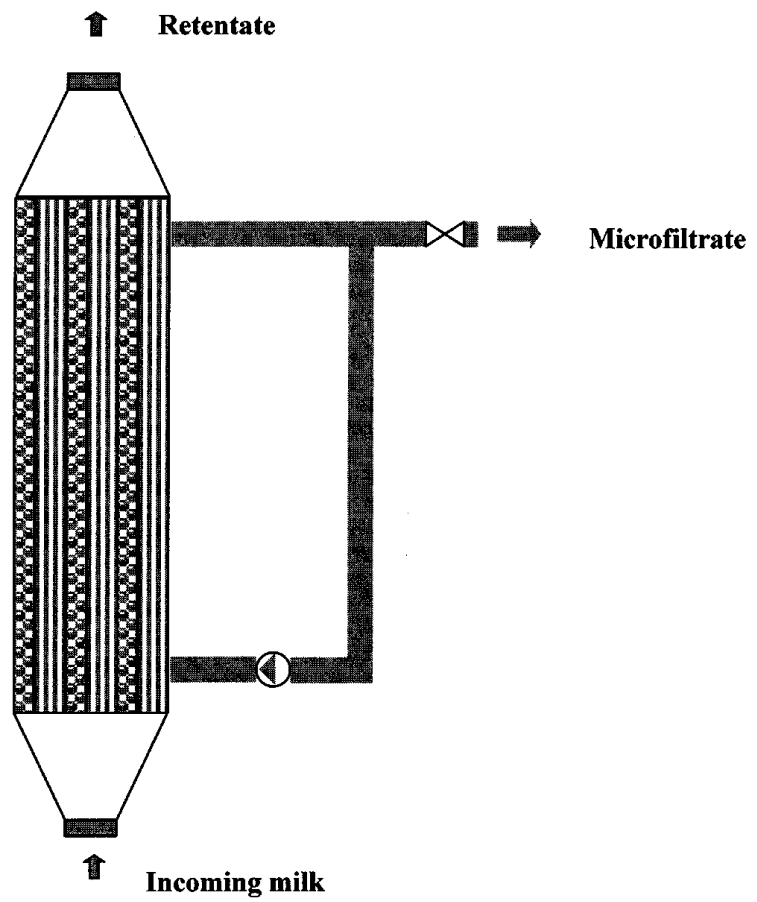

Pressure profiles

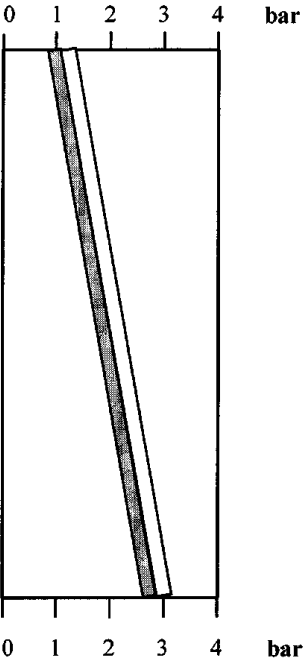

Figure 2. Pressure profiles during cross flow microfiltration.

Figure 2. Profil des pressions en microfiltration tangentielle.

milk are adjusted on the recirculated water. Finally, milk of which the physico-chemical equilibrium has been reestablished i.e. by a preheating of $50{ }^{\circ} \mathrm{C}$ for $20 \mathrm{~min}$, is progressively introduced in the MF retentate loop. The hydraulic parameters are readjusted during the first ten minutes before running in stationary conditions.

\subsection{Cleaning and sanitation of the MF equipment}

Cleaning of MF equipment is performed in the same way as for all membrane technologies with differences coming from the nature of the membrane material and from a demand for a higher degree of water quality. Indeed, water utilized for the rinsing steps as well as for the preparation of the different solutions must not contain suspended colloidal particles or microorganisms susceptible to cause an inside blocking of the membrane pores or an undesirable bacterial contamination of the cleaned equipment. Consequently, dwell and tap water must be not only softened but also microfiltrated on a $0.2 \mu \mathrm{m}$ dead end filter before being used for cleaning.

The cleaning cycle used includes:

- rinse with water heated at $50{ }^{\circ} \mathrm{C}$;

- alkaline cleaning with a ternary detergent such as Ultrasil ${ }^{\circledR} 25$ (Henkel) at a concentration of $0.5-1.0 \%$ or similar product at $65-70{ }^{\circ} \mathrm{C}$ for $20 \mathrm{~min}$ in the same operating conditions as the ones used for the applications;

- rinse with water at $50{ }^{\circ} \mathrm{C}$;

- facultatively sanitation with $\mathrm{ClONa}$ $200 \mathrm{ppm}$ at $20^{\circ} \mathrm{C}$ for $15 \mathrm{~min}$; 
- acid cleaning $\mathrm{NO}_{3} \mathrm{H} 0.5 \%$ for $20 \mathrm{~min}$ at $50{ }^{\circ} \mathrm{C}$ in the same operating conditions as those used for the alkaline step;

- rinse with water at $50{ }^{\circ} \mathrm{C}$.

Efficiency of the cleaning is checked by the water flux in defined conditions and by the bacteriological quality of the last rinse (no CFU in $100 \mathrm{~mL}$ ).

\section{APPLICATIONS OF MF IN THE DAIRY INDUSTRY}

The major application of MF in the dairy industry concerns the removal of microorganisms from skim milk in order to produce a debacterized raw material which is afterwards transformed into fluid milks, cheeses or long storage dairy products such as powder or protein derivatives. Another emerging application is the selective separation of micellar casein, which opens new avenues for better added values of milk components. Moreover these two main industrial developments, numerous other applications have been proposed which will be briefly reviewed here.

\subsection{Bacterial removal}

\subsubsection{Current development for the fluid milk industry}

Milk collected by the dairy plant always contains a microbial flora formed by numerous species illustrating the contaminations of milk by the udder, the milking machine, the local farm atmosphere, the bulk tank and the transportation equipment. Taking into consideration all these potential contaminations, one can say that whatever are or whatever will be the hygienic practices at farm level, the collected milk will be always contaminated. Cow husbandry cannot be done in aseptic conditions and milk will always have the risk of containing pathogenic bacteria for human beings such as Listeria, Brucella, Mycobacterium or Salmonella.
Destruction of the potentially risky flora has been done for fifty years by applying to milk heat treatments such as HTST pasteurization or UHT. But if heating effectively kills most of the microbial flora, the dead cells remain in the milk with their potentially active enzymes that with the metabolic activity developed by the growth of the remaining thermoduric bacteria, will cause alterations of liquid milks during storage, thus reducing shelf-life.

Membrane MF offers an interesting alternative to heat treatments. Initially proposed by Holm et al. [19] and Piot et al. [42], it has led to the technology and the equipment called "Bactocatch ${ }^{\circledR}$ " by the Tetra Laval Co. Numerous studies done in Sweden [25, 31] and in France [24, 26, 50, 51] have allowed improvements of the original parameters described in the patent of Holm et al. [19]. Nowadays, skim milk heated to $50{ }^{\circ} \mathrm{C}$ is circulated at a velocity of $7.2 \mathrm{~m} \cdot \mathrm{s}^{-1}$ along a Sterilox ${ }^{\circledR}$ membrane with an average pore size of $1.4 \mu \mathrm{m}$. The value of the uniform transmembrane pressure (UTP) is around 0.5 bar. The volumetric reduction factor (VRF) is 20 and in some huge equipment, the $5 \%$ flow represented by the MF retentate is concentrated 10 times more in cascade by a second MF apparatus, thus leading to a VRF of 200. Permeation rates of proteins and total solids are respectively higher than $99.0 \%$ and $99.5 \%$. Fluxes obtained industrially are in the order of $500 \mathrm{~L} \cdot \mathrm{h}^{-1} \cdot \mathrm{m}^{-2}$ during $10 \mathrm{~h}$.

Average observed decimal reduction (DR) is above 3.5 which means for an entering $20000 \mathrm{CFU} \cdot \mathrm{mL}^{-1}$ skim milk, the microfiltrated product contains less than $10 \mathrm{CFU} \cdot \mathrm{mL}^{-1}$. Spore forming bacteria which represent the main surviving species to pasteurization are better retained by MF membrane because of their large cellular volume as shown by Trouvé et al. [50]. The observed DR are higher than 4.5.

Synthesis of the studies done by Madec et al. [24], Pasteur Institute and INRA (data not published) shows for Listeria monocytogenes, Brucella abortus, Salmonella 
typhimurium and Mycobacterium tuberculosis respective DR of 3.4, 4.0, 3.5 and 3.7. Such results will assure that MF skim milk will contain less than $1 \mathrm{CFU} \cdot \mathrm{L}^{-1}$ of these pathogenic bacteria if we take into account usually described contaminations at farm level.

Somatic cells are evidently totally retained by the MF membrane and consequently MF milk will not be degraded by their thermoduric enzymes [22].

Several varieties of MF liquid milks are presently offered to the consumers. In France, the Marguerite ${ }^{\circledR}$ milk is considered to be a raw milk because no pasteurization is applied. The MF skim milk is mixed with the amount of heated cream $\left(95^{\circ} \mathrm{C}, 20 \mathrm{~s}\right)$ requested for fat standardization; the mixture is slightly homogenized and aseptically filled. The claimed shelf life at $4-6{ }^{\circ} \mathrm{C}$ is 15 days. In Scandinavia, Canada [7] and the UK [45], before aseptic filling a HTST $\left(72{ }^{\circ} \mathrm{C}, 15 \mathrm{~s}\right)$ heat treatment is applied, leading to a claimed shelf life of 35 days. These MF milks encounter great commercial success because of their flavor (no cooked taste) and their improved storage ability [7].

APV has patented a variant of the Bactocatch process which proposed the mixing of highly heat-treated MF retentate with cream and MF milk. Such a mixing is never done nowadays by the Bactocatch users. In the APV variant, the MF retentate, not heattreated, is returned to the raw milk entering the cream separator. Consequently, most of the bacteria as well as somatic cells are discharged through the separator sludge [34].

Use of smaller pore diameter $(0.5 \mu \mathrm{m}$ effective) recently proposed by Lindquist [23] has shown a bacteria removal increased by 2 or even $3 \log$ cycles compared to the $1.4 \mu \mathrm{m}$ pore diameter. Membranes utilized in this patent were either Membralox ${ }^{\circledR}$ or Pall $^{\circledR}$ ones set respectively in a classical cross flow equipment and in a Dynamic Membrane Filtration equipment. Decrease of pore size evidently leads to a slight decrease of casein micelles permeation rate but the bacterial epuration of the skim milk is so high (remaining count is less than $1 \mathrm{CFU} \cdot \mathrm{L}^{-1}$ ) that to obtain a fluid milk with a long shelf life at room temperature, a moderate heat treatment (less than $100{ }^{\circ} \mathrm{C}, 2 \mathrm{~s}$ ) is necessary. This new fluid milk is under commercial development and the first results (Fauquant, Madec and Maubois, data nonpublished) indicate a room temperature shelf life ranging from 6 to 9 months. Sensory tests show a flavor close to the one of HTST classical milks and much better than the current UHT milks.

As well as the use for the fluid milk sector, MF pretreatment of the skim milk can be expanded to all skim milk used for the production of milk derivatives such as low-heat milk powder as proposed by Schuck et al. [48], milk proteins concentrates or micellar casein powder [49]. On the other hand, MF milks, because of the removal of dead cells and somatic cells, offer to the dairy scientist the chance to study without any bias the exact effect of endogenous enzymes on milk components.

\subsubsection{Current developments for the cheese industry}

Cheese consumers wish to have the possibility to buy and to eat both cheeses with typical flavor and texture, characteristic of a geographical area i.e. cheeses belonging to their cultural patrimony, as well as more classical cheeses for daily consumption. As well as this diversified offer, the consumers also want a constant high quality and no hygienic risk. Such high requirements call for a complete control of the cheesemaking process starting from the raw material collected by the cheese plant.

Use of milks pretreated by MF with the same technology as described before for the fluid milk production i.e. a mixture of $\mathrm{MF}$ skim milk and heat-treated cream but sometimes with the variant of a lower MF temperature $\left(35-37{ }^{\circ} \mathrm{C}\right)$ in order to respect the raw milk labeling, offer to the cheese 
technologist a complete control of the raw material. Consequently, it can be claimed that cheeses made from MF milk are at least as safe from a hygienic point of view than cheeses made from pasteurized cheese milk. Moreover, because MF membrane removes, at a very high level, spore-forming bacteria such as Clostridium tyrobutyricum [31, 50], addition of nitrate at a level of $15 \mathrm{~g}$ per $100 \mathrm{~kg}$ as it is done in a few countries such as The Netherlands to prevent late blowing in semi hard or hard cheeses, could be suppressed with the positive consequences for environment and consumer health.

On the other hand, use of MF milk opens for the cheese scientist new ways to determine and to characterize the exact role played in cheese ripening by each microbial species or strain composing the ripening ecosystem, i.e., lactic acid bacteria, nonstarter lactic acid bacteria, propionibacteria, surface yeasts and molds [30], without the bias always introduced in the published studies by the use of heat sterilized milks, i.e., milks with the enzymatic potential of dead cells.

But, as described by Maubois et al. [30] use of MF milk in cheesemaking brings up numerous scientific and legal questions, particularly for AOP cheeses:

- Are they still raw milk cheeses? With current technology, removal of bacteria is done by $\mathrm{MF}$ at $35^{\circ} \mathrm{C}$ on about $90 \%$ of the cheese milk. The cream part is highly heattreated (generally $90-95{ }^{\circ} \mathrm{C}, 2$ or $3 \mathrm{~min}$ ). What are the effects of this heating on fat, on the globule membranes? What are the consequences on the casein network structure during formation and ripening by comparison with the use of a totally non-heated cheesemilk?

- Many studies demonstrate that natural flora plays a major role in the development of flavor and texture characteristics of AOP cheeses. Separation and concentration of this natural flora by MF is easy and as very well shown by Demarigny [6], a typical flora isolated from milks produced in a defined area $\mathrm{A}$ can be added to a MF milk obtained in another area B, even very far from A. That will originate a cheese in area B which has the same typicity as cheeses produced in area A. One sees easily the legal problems which arise from this possibility and the extent of delocalizations which could be thus created.

\subsection{Selective separation of micellar casein}

When whole or skim milk (evidently Bactocatch $^{\circledR}$ treated skim milk) is circulated along a MF membrane with a pore size diameter of $0.1-0.2 \mu \mathrm{m}$, a microfiltrate with a composition close to that of sweet whey is obtained [9]. This microfiltrate is crystal clear and it can be sterile and claimed without any viral particle [12] if the downstream equipment prevents recontamination. The MF retentate is an enriched milk solution of native micellar casein. Excepting the pore size of the MF membrane, engineering characteristics of the technology are the same as those used for bacteria removal of milk i.e. use of a device leading to a uniform transmembrane pressure, a retentate velocity of at least $7 \mathrm{~m} \cdot \mathrm{s}^{-1}$ and a running temperature of $50-55^{\circ} \mathrm{C}$. As proposed by Pierre et al. [38] and by Schuck et al. [48], purified micellar casein can be prepared according to this application of MF by following the process described in Figure 3 with three main steps:

(a) concentration of the MF retentate up to a VRF of 3-4;

(b) diafiltration of this MF retentate with 4 diavolumes of R.O. treated water;

(c) concentration of the diafiltered $\mathrm{MF}$ retentate up to a VRF of 6-7;

(d) spray-drying of the 6:1 MF retentate.

Many variants of this process can be envisaged such as use of UF instead of MF at step (c), diafiltration at lower or higher VRF or uses of saline or acid solutions for diafiltration instead of pure water. 


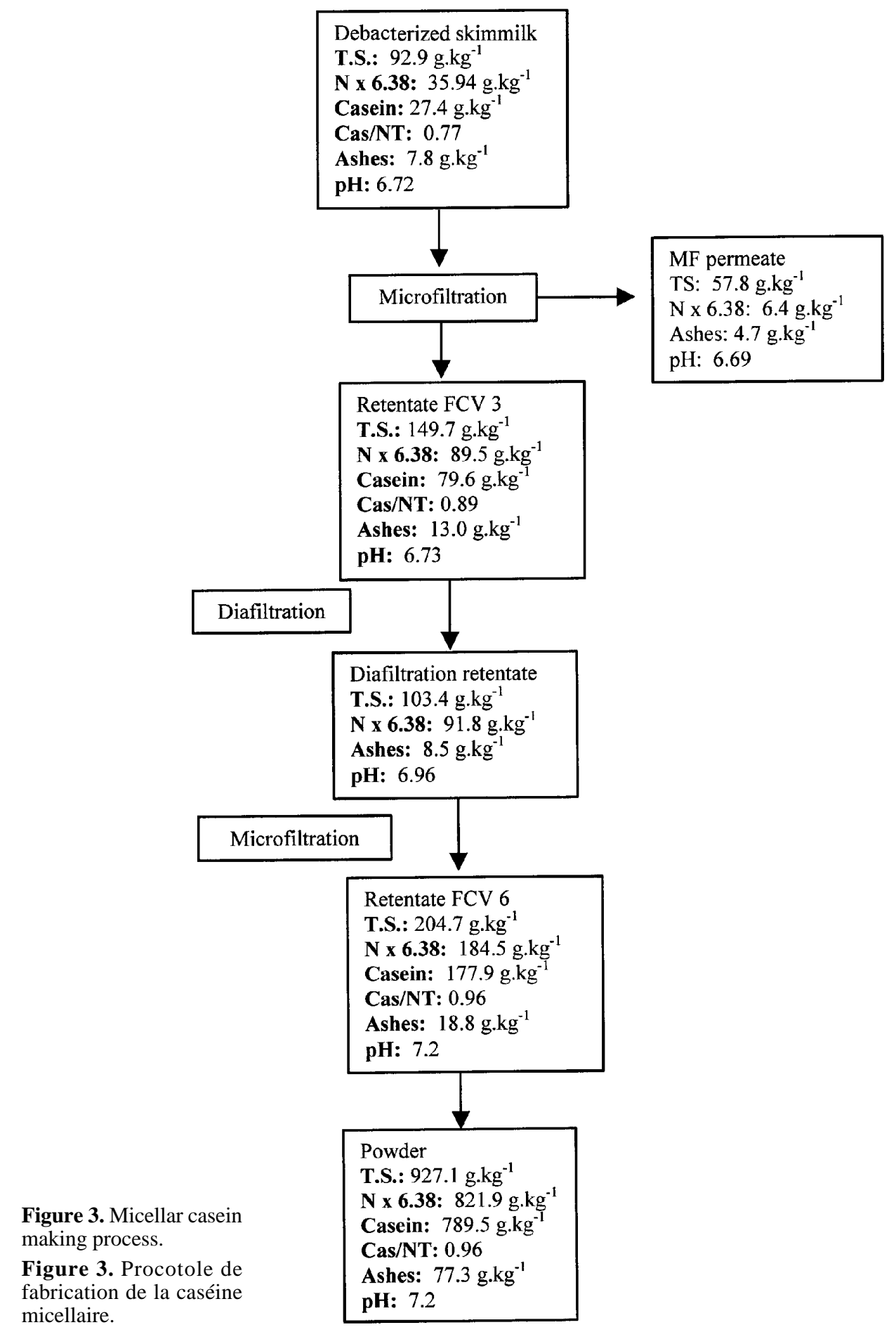


Micellar casein enriched milk improves cheesemaking process. Survey of the studies of Caron et al. [2], Saint-Gelais et al. [46] and Daviau et al. [4] demonstrates that such a MF milk coagulates slightly faster and leads to a more rigid curd (increase of the Young modulus with a coefficient of $30.5 \times 10^{3}$ Pa per $g$ of casein per kg of milk) and firmer curd (increase of fracture stress with a coefficient of $2.55 \times 10^{3}$ Pa per $g$ of casein per $\mathrm{kg}$ of milk). The yield increase in Camembert cheesemaking was $5.6 \mathrm{~g} \cdot \mathrm{kg}^{-1}$ per $g$ of casein increase in cheese milk [4].

Micellar casein powder which, to our knowledge, is not yet produced at an industrial scale, has large potentialities to be used for fortifying cheese milk, for replacing cheese curd in process cheese formulations. It also constitutes an excellent raw material for preparing individual caseins $(\beta-\mathrm{CN}$ notably) or $\kappa$-glycomacropeptide [28] in a strategy to produce purified nutraceutical derivatives from milk proteins [27].

On the other hand, partial removal by MF of whey proteins significantly reduces the detrimental effects of heating on rennet coagulability and cheese abilities of milk. To decrease the $\kappa$-casein/ $\beta$-lactoglobulin ratio will evidently lower the extent of formation of their complex during the heat treatment and consequently renneted micelles will aggregate almost as well as in raw milk [43]. This result was used to develop a new medium heat powder with such a cheesemaking ability that it can be used after reconstitution for the production with higher yields and good flavor characteristics of any cheese variety [11].

\subsection{Selective fractionation of globular milk fat}

Separation of milk fat in small globules and in large globules was recently proposed by Goudédranche et al. [17] through the use of special ceramic MF membranes which cause very low damage of the native globular membrane. It was claimed by the authors of this patented process that milks containing as fat only globules with a diameter lower than $2 \mu \mathrm{m}$ led to smoother and finer textural characteristic dairy products: cream, liquid milk, cheese etc. than those made from reference milks or from milks containing large fat globules with the exception of butter. The observed results were ascribed to the ability of fat globule membrane components to bind water and to the difference in triglycerides composition.

\subsection{Fat removal of whey}

The need to remove fat in whey protein concentrates was highlighted by de Wit [5] through his systematic approach to evaluation of functional properties notably the suitability of these dairy products as whipping ingredients. Numerous studies have been done to optimize the total removal of whey residual fat by MF after an aggregation pretreatment developed according to the results of Pearce [36], Maubois et al. [29], Baumy et al. [1], Gésan [13], Daufin et al. [3], and Pierre et al. [39]. The optimized procedure was described by Maubois and Ollivier [28]. It includes: (a) preconcentration by UF of the whey to $25 \%$ of its initial volume at $50{ }^{\circ} \mathrm{C}$; (b) removal of microorganisms by MF with a $0.8 \mu \mathrm{m}$ MF membrane set in an UTP equipment; (c) adjustment of temperature to $55^{\circ} \mathrm{C}$ and $\mathrm{pH}$ to 7.5 , this $\mathrm{pH}$ value being constantly maintained and (d) separation of the aggregated calcium phospholipid complex by MF with a $0.1 \mu \mathrm{m}$ pore size membrane set up in a UTP equipment. The so-obtained defatted whey concentrated by UF to a protein content of $10 \%$ shows foaming properties identical to egg white.

\subsection{MF and microbial fermentations}

As reviewed by Kulozik [21], membrane technologies and especially MF can be profitably incorporated in the upstream and downstream processing of the fermentation broth either in discontinuous operations for 
separating the biomass from the produced metabolites or in continuous fermentation processes. For example, MF equipment with a $0.1 \mu \mathrm{m}$ pore size membrane are connected to the fermentor to introduce aseptically sterile thermolabile components such as vitamins or salts. MF with $1.4 \mu \mathrm{m}$ ceramic membranes can achieve cell harvesting of starter bacteria with final concentration of the biomass increased to $10^{12}-10^{13} \mathrm{CFU} \cdot \mathrm{mL}^{-1}$ (Rolland and Proudy, data not published).

As well as the applications of MF in biofermentations of milk components, this separation technology has a great potential alone or in combination with nanofiltration (NF) for the treatment of dairy wastes through the carrying-out of membrane bioreactors. Indeed, activated sludges confined in a MF loop can easily degrade biological content of dairy effluents and thus restitute purified water to the environment.

\subsection{Cheese brine purification}

Efficient sanitation of cheese brine is required in the dairy industry in order to prevent post contamination of cheeses during salting. It is effectively well demonstrated that brine may contain unwanted microorganisms such as gas-producing lactobacilli, pathogenic bacteria (Staphylococci, Listeria and others) yeast and molds [35, 37]. As well as its bacterial load, the overall quality of brine and consequently the quality of the cheese salting, results from a relatively delicate balance equilibrium between $\mathrm{NaCl}$ content (18 to $26 \%$ ), soluble and precipitated $\mathrm{Ca}$ salts, lactose and lactic acid soluble and denaturated whey proteins.

Heat treatment and Kieselguhr filtration are still the most well-used technologies for brine treatment but both present many disadvantages: heat treatment requires expensive plate heat exchangers to avoid corrosion of usual stainless steel and modifies to an undesired extent the calcium phosphate equilibrium. Kieselguhr filtration needs manual handling, its dust is suspected to be carcinogenic [35] and anyway, disposal of Kieselguhr will be totally forbidden by law in European countries in 2002 for environmental reasons.

MF in a UTP equipment with a pore size of $1.4 \mu \mathrm{m}$ or $0.8 \mu \mathrm{m}$ membrane completely rejects yeasts and moulds, retains $99.9 \%$ of the contamination bacteria and only $6.7 \%$ of the calcium salts and $2-3 \%$ of the nitrogen matter [37]. The flux at $20^{\circ} \mathrm{C}$ was $600 \mathrm{~L} \cdot \mathrm{h}^{-1} \cdot \mathrm{m}^{-2}$ during $8 \mathrm{~h}$ and the concentration factor higher than $1: 100$.

From these very satisfactory results, it is likely that MF of cheese brine will expand rapidly if the investment cost of UTP ceramic membranes decreases as it can be expected.

\section{CONCLUSION}

With the use of membrane microfiltration technology, the world dairy industry has today a new powerful and flexible tool for a dramatic improvement of the hygienic safety of all dairy products while applying a minimal heat treatment to the milk. Consequently, it can be expected that nutritional and bioactive properties of milk components will be kept intact or at least little damaged in products derived from MF milk: liquid milks, cheeses, powders, fermented products, etc. Removal of bacterial and somatic cells with their endogenous thermoduric enzymes offers moreover to dairy research the chance to determine without any bias the precise activity versus storage time and temperature conditions of endogenous milk enzymes. The same research area is also opened for studying the metabolic consequences of each component of the microbial ecosystem added to MF cheesemilks.

Specific separations of micellar casein and of small and large fat globules open to dairy technology new and diversified avenues not only for improving current manufacturing processes, and consequently overall quality of resulting products, but also for 
creating new milk derivatives answering to the constant needs of novelty of the world dairy consumers.

\section{ACKNOWLEDGEMENTS}

Funding support of Ms Luciana Saboya's grant by CAPES and FAPESP is greatly acknowledged.

\section{REFERENCES}

[1] Baumy J.J., Gestin L., Fauquant J., Boyaval E., Maubois J.L., Technologies de purification des phospholipides du lactosérum, Process 1047 (1990) 29-33.

[2] Caron A., Saint Gelais D., Pouliot Y., Coagulation of milk enriched with ultrafiltered or diafiltered microfiltered milk retentate powders, Int. Dairy J. 9 (1997) 445-451.

[3] Daufin G., Labbé J.P., Quemerais A., Michel F., Merin U., Optimizing clarified whey ultrafiltration: influence of $\mathrm{pH}$, J. Dairy Res. 61 (1994) 355-363.

[4] Daviau C., Effet des caractéristiques physicochimiques du lait sur l'aptitude à la coagulation présure et à l'égouttage dans une technologie pâte molle, Ph.D. thesis, INRA, Rennes, France, 2000.

[5] de Wit J.N., Functional properties of whey proteins in food systems, Neth. Milk Dairy J. 38 (1984) 71-89.

[6] Demarigny Y., Rôle de la flore naturelle du lait cru et de paramètres technologiques (teneur en sel et température d'affinage) sur l'évolution des caractéristiques biochimiques, microbiologiques et sensorielle des fromages à pâte cuite, Ph.D. thesis, INRA, Poligny, France, 1997.

[7] Eino M.F., Lessons learned in commercialization of microfiltered milk, Bull. Int. Dairy Fed. 320 (1997) 32-36.

[8] Fauquant J., Vieco E., Brulé G., Maubois J.-L., Clarification des lactosérums doux par agrégation thermocalcique de la matière grasse résiduelle, Lait 65 (1985) 1-20.

[9] Fauquant J., Maubois J.-L., Pierre A., Microfiltration du lait sur membrane minérale, Tech. Lait. 1028 (1988) 21-23.

[10] Garcera D., Toujas E., (Société des Céramiques Techniques) Support macroporeux à gradient de perméabilité et son procédé de fabrication Demande de Brevet No. 97.04.359, 1998.

[11] Garem A., Schuck P., Maubois J.-L., Cheesemaking properties of a new dairy-based power made by a combination of microfiltration and ultrafiltration, Lait 80 (2000) 25-32.
[12] Gautier M., Rouault A., Méjean S., Fauquant J., Maubois J.-L., Partition of Lactococcus lactis bacteriophage during the concentration of micellar casein by tangential $0.1 \mu \mathrm{m}$ pore size microfiltration, Lait 74 (1994) 419-423.

[13] Gésan G., Daufin G., Merin U., Labbé J.P., Quémerais A., Fouling during constant flux cross-flow microfiltration of pretreated whey. Influence of transmembrane pressure gradient, J. Membr. Sci. 80 (1993) 131-146.

[14] Gillot J., Garcera D., New ceramic filter medium for cross-flow microfiltration, in: FILTRA Congress, Paris, France, 1984, pp. 2-4.

[15] Gillot J., Garcera D., Ceraver: nouveaux médias filtrants céramiques, Tech. Lait. 1007 (1986) 23

[16] Glimenius A.R., Jansson G.T., Kemi K.W., Sandblom R.M., Filtering method for separating skim milk from milk products, US Pat. No. 4.140.806, 1979 .

[17] Goudédranche H., Fauquant J., Maubois J.-L., Fractionation of globular milk fat by membrane microfiltration, Lait 80 (2000) 93-98.

[18] Grandison A.S., Finnigan T.J.A., Microfiltration, in: Grandison A.S., Lexis M.J. (Ed.), Separation process in the food and biotechnology industries, Woodhead Publ. Ltd., Cambridge, England, 1996, pp. 141-153.

[19] Holm S., Malmberg R., Svensson K., Method and plant for producing milk with a low bacterial content, Eur. Pat. No. 0.194.286, 1984.

[20] Jost R., Jelen P., Cross-flow microfiltration an extension of membrane processing of milk and whey, Bull. Int. Dairy Fed. 320 (1997) 9-15.

[21] Kulozik U., Membranes in microbial fermentations, Bull. Int. Dairy Fed. Special issue 9201 (1992) 141-160.

[22] Law B.A., Goodenough P.W., Enzymes in milk and cheese production, in: Tucker G.A., Woods L.F.J. (Eds.), Enzymes in Food Processing, Blackie Acad. \& Professional, Glasgow, UK, 1995, pp. 114-143.

[23] Lindquist A., A method for the production of sterile skimmed milk, PCT Pat. WO No. 57549, 1998.

[24] Madec M.N., Méjean S., Maubois J.-L., Retention of Listeria and Salmonella cells contaminating skim milk by tangential membrane microfiltration (Bactocach process), Lait 72 (1992) 327-332.

[25] Malmberg M., Holm S., Low bacteria skim milk by microfiltration, North Eur. Food Dairy J. 54 (1998) 75-78.

[26] Maubois J.-L., Current uses and future perspectives of MF technology in the dairy industry, Bull. Int. Dairy Fed. 320 (1997) 37-40.

[27] Maubois J.-L., Léonil J., Peptides du lait à activité biologique, Lait 69 (1989) 245-269.

[28] Maubois J.-L., Ollivier G., Extraction of milk proteins, in: Damodaran S., Paraf A. (Eds.), Food proteins and their applications, Marcel Dekker, Inc., New York, 1997, pp. 579-595. 
[29] Maubois J.-L., Pierre A., Fauquant J., Piot M. Industrial fractionation of main whey proteins, Bull. Int. Dairy Fed. 212 (1987) 154-159.

[30] Maubois J.-L., Caudron B., Daviau C., Madec M.N., Pierre A., Membrane technologies: tools for a total control of the cheesemaking process, IDF Banff 2000 Seminar.

[31] Meershon M., Nitrate free cheesemaking with Bactocatch, North Eur. Food Dairy J. 55 (1989) 108-113.

[32] Merin U., Bacteriological aspects of microfiltration of cheese whey, J. Dairy Sci. 69 (1986) 326-328.

[33] Merin U., Gordin S., Tanny G.B., Microfiltration of sweet cheese whey, J. Dairy Res. 18 (1983) 153-160.

[34] Osterland N., Removal of bacteria and spores from milk by microfiltration, in: Proc. INRA Int. Dairy Fed. Seminar, New applications of membrane technology in the dairy industry, Saint Malo, France, 1999, p. 18

[35] Ottosen N., Konigsfeld P., Microfiltration of cheese brine, Eur. Dairy Mag. 4 (1999) 22-24

[36] Pearce R.J., Thermal separation of $\beta$-lactoglobulin and $\alpha$-lactalbumin in bovine Cheddar cheese whey, Aust. J. Dairy Technol. 42 (1983) 75-78.

[37] Pedersen P.J., Microfiltration for the reduction of bacteria in milk and brine, Bull. Int. Dairy Fed. Special issue 9201 (1992) 33-50.

[38] Pierre A., Fauquant J., Le Graet Y., Piot M. Maubois J.-L., Préparation de phosphocaséinate natif par microfiltration sur membrane, Lait 72 (1992) 461-474.

[39] Pierre A., Le Graet Y., Daufin G., Michel F., Gésan G., Whey microfiltration performance: influence of protein concentration by ultrafiltration and of physicochemical pretreatment, Lait 74 (1994) 65-77.

[40] Pierre A., Goudédranche H., Garem A., Daufin G., Industrie Laitière, in: Daufin D., René F. Aimar P. (Coords.), Les séparations par membrane dans les procédés de l'industrie alimentaire, Tec. Doc. Lavoisier, Paris, 1998 pp. 282-371.
[41] Piot M., Maubois J.-L., Schaegis P., Veyre R., Microfiltration en flux tangentiel des lactosérums de fromagerie, Lait 64 (1984) 102-120.

[42] Piot M., Vachot J.C., Veaux M., Maubois J.-L., Brinkman G.E., Écrémage et épuration bactérienne du lait entier cru par microfiltration sur membrane en flux tangentiel, Tech. Lait. Market. 1016 (1987) 42-46.

[43] Quiblier J.P., Ferron-Baumy C., Garric G., Maubois J.-L., Procédé de traitement des laits permettant au moins de conserver leur aptitude fromagère, Brevet Fr. No. 0.542.583 B1, 1992.

[44] Rios G.M., Tarodo de la Fuente B., Bennasar M., Guidard C., Cross-flow filtration of biological fluids on inorganic membranes: A first state of the art, in: Thorne S. (Ed.), Developments in Food Preservation, Elsevier Applied Science, London, UK, 1989, pp. 131-175.

[45] Russell P., A new fresh milk comes to Britain, Eur. Dairy Mag. 3 (1999) 25-27.

[46] Saint-Gelais D., Roy D., Audet P., Manufacture and composition of low fat Cheddar cheese from milk enriched with different protein concentrate powders, Food Res. Int. 31 (1998) 137-145.

[47] Sandblom R.M., Filtering process, SW Pat. No. 74.16.257, 1974.

[48] Schuck P., Piot M., Méjean S., Le Graet Y., Fauquant J., Brulé G., Maubois J.-L., Déshydratation des laits enrichis en caséine micellaire par microfiltration, comparaison des proprietés des poudres obtenues avec celles d'une poudre de lait ultra-propre, Lait 74 (1994) 47-63.

[49] Schuck P., Piot M., Méjean S., Le Graet Y. Fauquant J., Brulé G., Maubois J.-L., Déshydratation par atomisation de phosphocaséinate natif obtenu par microfiltration sur membrane, Lait 74 (1994) 375-388.

[50] Trouvé E., Maubois J.-L., Piot M., Madec M.N. Fauquant J., Rouault A., Tabard J., Brinkman G., Rétention de différentes espèces microbiennes lors de l'épuration du lait par microfiltration en flux tangentiel, Lait 71 (1991) 1-13.

[51] Vincens D., Tabard J., L'élimination des germes bactériens sur membranes de microfiltration, Tech. Lait. 1033 (1988) 62-64. 
